\title{
Metaphorical Perceptions of Prospective Teachers for STEM Education ${ }^{i}$
}

\author{
Hamza Çalışıcı ${ }^{*}$, Özlem Özçakır Sümen
}

Faculty of Education, Ondokuz Mayıs University, Turkey

Copyright $\bigcirc 2018$ by authors, all rights reserved. Authors agree that this article remains permanently open access under the terms of the Creative Commons Attribution License 4.0 International License

\begin{abstract}
In this study, the perceptions of prospective classroom teachers on science, technology, engineering and mathematics (STEM) education approaches have been examined through metaphors. The participants in this qualitative research project included 138 prospective teachers studying between the 2016-2017 academic year in the department of elementary education from the faculty of education at a public university in Turkey. In order to determine the perceptions of STEM teachers selected from different class levels, the prospective teachers were first educated about STEM education. Next, a form, on which the statement, "STEM Education (Science-Technology-Engineering-Mathematics) is like ...because ... " was presented to the prospective teachers, and they were asked to write a metaphor for STEM education, as well as to explain the reason. The data obtained from the forms were analyzed through content analysis. From the data analysis, the valid metaphors on STEM education created by the prospective classroom teachers were collected under 9 different conceptual categories, which were developed on the basis of common characteristics. These categories reveal that the prospective teachers regard STEM as a useful, necessary and highly appreciated approach that involved complementary fields. In some categories, it was found that there were significant differences in the rate of participants according to gender and class level.
\end{abstract}

Keywords STEM Education, Prospective Teacher, Metaphor

\section{Introduction}

Science, technology, engineering and mathematics (STEM) education is an educational approach that focuses on the interdisciplinary nature of these fields. STEM is the purposive integration of various disciplines applied to solve real-life problems, and STEM is particularly important in that "Technology" and "Engineering" play such a critical role in the 21 st century's economy $[1,2]$. The STEM approach merges the independent disciplines of science, technology, engineering and mathematics into one unit; thus, the integrated disciplines are taught as one cohesive entity [3]. The interdisciplinary curriculum forming the basis of the STEM educational approach is holistic in nature, in that it combines disciplines to facilitate relevant, focused, meaningful, and purposeful learning for students [4].

The concept of STEM literacy is emphasized in relation with STEM education in the literature. Bybee [5] argues that STEM literacy should be turned into an educational priority for all students as soon as possible. STEM literacy means defining, using, and integrating STEM concepts to understand complex problems and to solve them innovatively [6]. Bybee [5] describes the STEM literacy skills as follows:

1) Using it for acquiring knowledge about science, technology, mathematics and engineering and adding new knowledge, defining the subjects and learning about topics related to STEM,

2) Understanding the STEM characteristics of human activities covering research, analysis and design processes,

3) Understanding how STEM disciplines shape our material, intellectual and cultural world,

4) Engaging in STEM-related matters as interested, affective and constructive citizens.

Although many countries in the world have been developing in STEM fields, the ratio of US students in STEM fields is decreasing at an alarming rate [7]. In international examinations conducted in recent years, it has been observed that the success of American students has decreased to below the average of OECD countries $[8,9]$. The pioneers of STEM education argue that science and mathematics topics are more effective when integrated with technology and engineering concepts, and that through this integration of fields students will be better 
prepared for STEM professions [10]. In the United States, several pieces of legislation have been enacted regarding STEM education, with the goal being that more students will become proficient in these disciplines [11, 12].

STEM education has been spreading to many countries, and STEM applications have become more and more popular in the education systems of countries. Studies on STEM education have also intensified in recent years on the following issues: strategies that can be applied in high school STEM education [13]; the mathematical standards related to STEM integration into educational programs (on documents such as NCTM) [14]; the organization of STEM activities in high school technology and engineering courses [15], how researchers conceptualize STEM in faculties [3], the organization of STEM activities in science classes [16]; maker movement within the scope of STEM education [17] and the introduction of robot kits [18], and the experiences of young students with STEM education and its impact on the continuation of their careers [19]. An example of such a study would be the one conducted by Han, Capraro and Capraro [20], who attempted to determine how participation in STEM project-based learning activities affected student performance level and mathematical achievements. At the end of the three-year study, underperforming students who underwent STEM education had higher improvement in mathematical grades at a statistically higher rate compared to that of students with medium and high performance. STEM project-based learning was therefore shown to be more beneficial for students having low performance at schools, the results of which suggest that the gap between low- and high-performing students can be reduced. Furthermore, a 2-week STEM camp for secondary school students-the follow-up study of which showed learning experiences in informal STEM education environments provided significant benefits for the secondary school students, such as awareness of STEM topics and careers - increased the students' enthusiasm, self-efficacy and content knowledge [21]. A STEM training program using robots to improve computational thinking skills was given to 5th grade teachers and students. Analysis of the data related to the use of this program revealed that the integrative program facilitated cognitive development and stronger problem-solving skills in students and improved teacher practices in supporting cognitive demands [22]. The participation of students in computer-based learning activities in mathematics classes has a positive effect on their choice of STEM branches [23].

Priorities have also been given to STEM education in Turkey, where studies on STEM have been carried out by the Ministry of National Education (MNE), as well as academicians. In the action report prepared by MNE on STEM in June 2016, the primary actions to be performed in this area were stated as follows: Establishment of STEM training centers, ensuring the cooperation between the centers established and the universities, the training of teachers in this area, and updating the curriculum and preparing the course materials for the program [24]. Çorlu emphasizes the importance of having a highly qualified STEM workforce to improve the innovation capacity of Turkey and of raising teachers who are capable of providing STEM education; however, teachers often lack the necessary integrated teaching knowledge to provide effective STEM teaching and learning opportunities.

To better ensure the success of this process, it is important to determine the perceptions and perspectives of prospective teachers regarding STEM education. One way to do this is through metaphors. A metaphor is a figure of speech used to describe a concept by comparing it with other familiar concepts. Metaphors are commonly used to discover and understand something abstract, new, or hidden [26]. Furthermore, a metaphor is a type of behavior involving the identification and use of structural or dynamic characteristics that do not vary, and verbal metaphors are real explanations of the transformation in understanding the essential topic [27]. In developing them, metaphors serve to reflect, shape, and ultimately direct human behavior [28], and as such they play an important role as reflection and awareness-raising tools among educators. Metaphors organize thought and shape our way of perceiving the world and reality [29]. One of the ways of increasing teachers' awareness of the belief systems is to focus on the metaphors and imagery they use to describe their teaching [30]. Metaphor studies related to STEM education are not yet available in the literature. Therefore, it is believed this study, which examines the metaphorical perceptions of prospective teachers on STEM education, will contribute to the field. Accordingly, the sub-problems of the study can be listed as follows:

- What metaphors do prospective classroom teachers use to describe STEM education?

- In which conceptual categories can these metaphors be grouped in terms of common features?

- How do these metaphors vary according to gender and class levels of prospective teachers?

\section{Method}

Qualitative research methods were used in the research. The data were collected through metaphors. This type of data collection is a more practical and easier method compared to interviewing, observing or examining a document. With one or more open-ended questions, very rich metaphors can be obtained from the person interviewed. In addition to simplicity and easiness, metaphors provide a very solid, broad picture of the subject, case, event and situation studied [31]. The study of metaphor has gained acceptance as a legitimate alternative to conservative and conventional approaches in exploring how participants think [32]. Metaphor has the power to 
enhance the subject's understanding of educational problems and thus increase perspective-consciousness [33]. Guided by the premise that metaphors help people to make connections between things they know and things less familiar [34], it was assumed that the prospective teachers would be better able to explain STEM education by making a metaphor. Accordingly, this study sought to determine how prospective classroom teachers conceptualize their thoughts about STEM education through metaphors.

\subsection{Participants}

The research was conducted in the faculty of education of a public university in Turkey in the 2016-2017 academic year. A total of 138 prospective teachers studying in the classroom teaching department participated in the study. Among this total, 103 were female and 35 were male; 57 were in their first year, 33 in their second year, 34 in their third year, and 14 in their fourth year.

\subsection{Data Collection Tools}

A form was developed on the basis of the literature, by the researchers in order to determine the perceptions of the prospective teachers on STEM education; expert opinion was also taken in developing this form. In addition to questions related to personal information of the prospective teachers, the form included the statement, "STEM Education (Science-Technology-Engineering-Mathematics) is like ... because ..." to get the prospective teachers to write metaphors about STEM education.

\subsection{Applications}

Prior to the collection of data, training on the STEM approach was given to the prospective teachers. In this training, the emergence, purpose, and content of the STEM education approach were explained to the prospective teachers. Afterwards activities related to STEM education and how it is applied in different areas were presented. In addition, examples of the STEM approach were shown to help the prospective teachers understand the concept behind the approach. At the completion of this process, the form developed by the researchers was distributed to the prospective teachers, and they were asked to write a metaphor for STEM education and explain its reason.

\subsection{Analyzing Data}

The metaphors that the prospective teachers put forward on the STEM education approach were analyzed through the content analysis technique. The main purpose in content analysis is to identify relations that can explain the obtained data. To do this, the collected data are first conceptualized, and then these concepts are arranged in a logical order. The features explaining the data are themed accordingly [31]. The metaphors developed by the participants were analyzed according to the stages proposed by Saban [35], namely, coding and sorting, compiling sample metaphor images, developing categories, and securing validity and reliability.

In the coding and sorting phase, the metaphors created by the prospective teachers were examined one by one in order to understand whether they expressed the metaphors they wrote in a clear way. Subsequently, the metaphor papers were numbered to show the class levels of the prospective teachers (for example; F1.10 = female student numbered 10 in the first year and M4.8 = male student numbered 8 in the fourth year) and were coded according to the metaphor images they included. At this stage, 14 metaphorical papers which did not include a metaphor image and/or did not provide any reason for the written metaphor image, and/or was believed by the researchers to provide no contribution to the understanding of the STEM education approach were excluded from the analysis. For example, while the metaphor, "STEM education is like a rainbow because if you find the end of the rainbow you become rich" is clear, the logical reason for the metaphor is unclear. This statement, therefore, fails to make any contribution to the understanding of STEM education.

During the compilation phase of the sample metaphor image, the remaining 124 pieces of raw data were re-examined after being sorted, and the valid metaphor categorizations were determined according to the justifications. For the representation of these categories, the examples of metaphorical expressions from the justifications of the prospective teachers were selected. Thus, a sample metaphor list was created for each of the metaphorical groups from the participant metaphor images assumed to best represent them, and the frequencies of metaphors were calculated.

During the category development phase, metaphors analyzed according to the content analysis and classified according to the reasons were associated with the specific themes based on the consensus of the researchers. These themes were named in such a way as to reflect the reasons for the metaphors, and a total of nine different conceptual categories were created.

In qualitative research, detailed reporting of the collected data and explanations of how the researcher arrives at the results are among the important criteria of validity [31]. In the phase of ensuring the validity and reliability of the study, the manner in which the conceptual categories were created is explained in detail. In the Findings section, the metaphors written by the prospective teachers are individually numbered, and direct quotations from the participant views are presented. To test the reliability of the study, expert opinion was taken about the content analysis. Examples of the metaphor images developed and the conceptual categories created for this 
purpose were shown to an expert, who was asked to compare and match the data with the original. The classification made by the expert was compared with the classification made by the researchers, and the differences were discussed again to reach a common opinion. According to the consensus, the valid metaphor images and conceptual categories were reorganized to arrive at the final form of the data analysis. It is believed that the consensus of the expert and the researcher in the data analysis improved the reliability of the study.

\section{Findings}

In this section, the metaphors written by the prospective classroom teachers about STEM education and the categories associated with them are presented.

Table 1. Metaphors under the category of STEM as mutually complementary areas

\begin{tabular}{|c|c|c|}
\hline Metaphors & Prospective Teachers & $\mathrm{f}$ \\
\hline Olla Podrida & $\begin{array}{c}\text { F1.93 / M3.132 / M3.128 / F2.55 / F3.3 / } \\
\text { F3.29 / F1.107 }\end{array}$ & 7 \\
\hline Watch & $\begin{array}{c}\text { M3.26 / F2.34 / F3.11 / F3.131 / M1.66 / } \\
\text { M4.20 }\end{array}$ & 6 \\
\hline Chain & F3.10/F1.90/ F1.89 / F1.102 / F1.82 & 5 \\
\hline Colors & F1.81 / F3.137 / F2.35 / F3.130 & 4 \\
\hline Puzzle & F1.75 / F4.88 / F1.73 / M4.74 / & 4 \\
\hline Sibling & F2.44 / F3.37 / F1.70/F3.33 & 4 \\
\hline $\begin{array}{c}\text { Four-Legged } \\
\text { Stool }\end{array}$ & F4.17 / M4.8 / F1.119 & 3 \\
\hline Football & M3.13 / M1.83 & 2 \\
\hline Picture & F3.32 / F1.52 & 2 \\
\hline & Total & 37 \\
\hline
\end{tabular}

Table 1 presents the metaphors that fell under the category of STEM as mutually complementary areas. Prospective teachers produced nine valid metaphors under this category, namely, olla podrida, watch, chain, colors, puzzle, sibling, four-legged stool, football, and picture. The most frequently applied metaphor from these categories was olla podrida, which some of the prospective teachers $(\mathrm{f}=7$ ) used to describe STEM education, referring to it as a new meal composed of different tastes coming together. One prospective teacher expressed his view on this subject as follows: "STEM is like olla podrida because the meal is made by mixing all vegetables together. Although all the vegetables seem independent from each other, they merge to create the whole of the meal. STEM is also the same" (F1.93). As seen in the table, many prospective teachers likened STEM education to watches. This can be explained by the fact that while the different parts have no meaning alone, together they form a meaningful and necessary whole, that is, the watch. Through these metaphors, the prospective teachers communicated that science, technology, engineering and mathematics are fields that complement and support each other, and that these areas combine to form a meaningful whole. One prospective teacher who equated STEM to a puzzle stated, "STEM is like a puzzle, because each of the component parts is like a piece of the puzzle. In my opinion, when there is one without the other, something is missing; they complement each other" (F1.73). It was also stated by one prospective teacher that the lack of one of these areas would affect the others, using the metaphor of a four-footed stool. This idea was further expressed using the following metaphor: "STEM is like a four-legged stool, because if there is a problem on any one of the four legs of a stool, the entire system is hindered" (F4.17).

Table 2. Metaphors under the category of STEM as a useful approach

\begin{tabular}{|c|c|c|}
\hline Metaphors & Prospective Teachers & $\mathrm{f}$ \\
\hline $\begin{array}{c}\text { Mobile } \\
\text { phone }\end{array}$ & $\begin{array}{c}\text { F2.28 / F1.84 / M1.79/ M1.80 / F1.104 / } \\
\text { F3.129/F2.48 / F2.50 }\end{array}$ & 8 \\
\hline $\begin{array}{c}\text { Close } \\
\text { Friend }\end{array}$ & M2.30/F3.12/ M2.64 / F4.16/ M4.24 & 5 \\
\hline $\begin{array}{c}\text { Water } \\
\text { Cycle }\end{array}$ & $\mathrm{F} 3.139 / \mathrm{M} 2.62 / \mathrm{F} 2.54 / \mathrm{F} 2.53 / \mathrm{F} 4.15$ & 5 \\
\hline Sport & $\mathrm{F} 3.133 / \mathrm{F} 1.91 / \mathrm{F} 1.115$ & 3 \\
\hline $\begin{array}{c}\text { Building } \\
\text { Column }\end{array}$ & $\mathrm{F} 1.85 / \mathrm{F} 1.116$ & 2 \\
\hline Green & $\mathrm{F} 1.121 / \mathrm{F} 1.106$ & 2 \\
\hline Game & $\mathrm{F} 3.135 / \mathrm{F} 2.42$ & 2 \\
\hline Milk & Total $27 / \mathrm{F} 2.65$ & 29 \\
\hline
\end{tabular}

As seen in Table 2, the most frequently used metaphor under the category of STEM as a useful approach was mobile phone $(\mathrm{f}=8)$. Many of the prospective teachers see the mobile phone as very useful and indispensable. They also believe that STEM education is as useful as a mobile phone. The following is one of the metaphors used by a prospective teacher on this subject: "STEM is like a mobile phone because we can communicate with everyone by means of mobile phones. These sciences also make our life easier" (F2.28). In addition to mobile phone, close friend, water cycle, sport, building column, green, game, and milk were other metaphors applied under the 'useful approach' category. These metaphors identified in the data analysis reveal that the prospective teachers regarded STEM education as a beneficial and useful approach. Using the metaphor of sports, one prospective teacher wrote, "STEM is like sports; life will go on without sports but we continue our lives in a much more energetic way with them. In other words, practicing it is much more useful" (F3.133). The prospective teachers pointed out that this approach would contribute to the education system and to the development of the students and felt that STEM would benefit students in many ways. For example, one teacher stated, "STEM is like milk, because lots of products are obtained from milk. It is very useful for health" (F2.27). 
Table 3. Metaphors under the category of STEM as a needed approach

\begin{tabular}{|c|c|c|}
\hline Metaphors & Prospective Teachers & $\mathrm{f}$ \\
\hline Water & $\begin{array}{c}\text { F2.59/F1.69 / F1.74 / M1.98 / F1.315 / F1.123 / } \\
\text { F1.125 / F3.127 }\end{array}$ & 8 \\
\hline Sun & $\mathrm{F} 1.103 / \mathrm{F} 2.61 / \mathrm{F} 2.51 / \mathrm{F} 2.63 / \mathrm{F} 1.87$ & 5 \\
\hline Heart & $\mathrm{F} 1.108 / \mathrm{F} 1.114 / \mathrm{F} 1.117$ & 3 \\
\hline Make-up & $\mathrm{F} 1.113$ & 1 \\
\hline Telephone & $\mathrm{F} 1.67$ & 1 \\
\hline & Total & 18 \\
\hline
\end{tabular}

Table 3 presents the metaphors under the category of STEM as a needed approach. The metaphors applied in this category included water, sun, heart, make-up, and telephone. Prospective teachers who put forth these metaphors stated that STEM was a necessary and required approach in education. For example, the water metaphor expressed under this category actually proves that the prospective teachers see these disciplines as substantial, needed areas. The metaphor offered by one prospective teacher stated "STEM is like water, because STEM education is necessary for education just like the way water is needed for human health" (F2.59). Other metaphors, like the sun and the heart, found under this category show how vital and indispensable STEM education is: "STEM is like the sun, because all fields shed light on each other. Just like the sun, STEM is also vital. In order to raise a good future generation STEM should always be present" (F1.103). One prospective teacher, who likened STEM to a heart, explained it as follows "STEM is like heart, because without STEM, education fails to work properly and has no efficiency. Education stops where there is no STEM education. That is why I think STEM is like the heart. Vital activities stop without the function of the heart" (F1.108).

Table 4. Metaphors under the category of STEM as an approach containing different disciplines

\begin{tabular}{|c|c|c|}
\hline Metaphors & Prospective Teachers & $\mathrm{f}$ \\
\hline Hamburger & M2.41 / F2.49 / F2.52 / F4.9/F3.21 & 5 \\
\hline Life & M4.23 / F3.38/F1.76 & 3 \\
\hline Musical & F2.40/F2.43 / M4.25 & 3 \\
\hline Rainbow & F3.5 & 1 \\
\hline Total & & 12 \\
\hline
\end{tabular}

The metaphors shown in Table 4 reveal that the prospective teachers regard STEM education as an interdisciplinary approach. They stated that STEM education was an approach that involved a combination of these areas, where each has an equal role and work in cooperation. The most frequently applied metaphor in this category was hamburger $(\mathrm{f}=5)$. With the hamburger metaphor, prospective teachers' equated STEM education to fare that consisted of various foods: "STEM is like a hamburger, because it has everything in it. In other words, I liken it to a combination of education methods" (F4.9). The other metaphors in this category included life, musical and rainbow. Three prospective teachers likened STEM education to life and emphasized that STEM was made up of different fields: "STEM is like life, because life includes all the relations among science, nature, environment, mathematics and engineering. It explains the perfect relation in life. It exists in every area of life" (M4.23). The prospective teacher who compared STEM to a rainbow described it as follows: "STEM is like a rainbow, because it provides different beauties related to the colors of the rainbow. Just as the rainbow has different colors, this system may also have differences" (F3.5)

Table 5. Metaphors under the category of STEM as a highly liked approach

\begin{tabular}{|c|c|c|}
\hline Metaphors & Prospective Teachers & $\mathrm{f}$ \\
\hline Chocolate & F3.100/F3.126/ M1.105/M1.96/F2.47 & 5 \\
\hline Hurricane & M1.92/ F1.111 & 2 \\
\hline Polar Star & F2.60/ M1.71 & 2 \\
\hline Total & & 9 \\
\hline
\end{tabular}

Another category to emerge as the result of the data analysis was the metaphor of STEM as a highly liked approach. This result shows that the prospective teachers liked STEM education. As seen in Table 5, there were three metaphors under this category: chocolate, hurricane and polar star. The most frequently used metaphor under this category was chocolate. Teacher candidates' chocolate metaphor demonstrates how much they liked STEM education and viewed it as an indispensable education approach. This can be seen in one of the prospective teacher's metaphor, which stated, "STEM is like chocolate, once you get used to it, you cannot quit it" (F3.100). For the hurricane metaphor under this category, a prospective teacher shared, "STEM is like a hurricane, because if this system is fully implemented in our country and if a high level of efficiency is achieved, it will destroy all obstacles, like a hurricane" (M1.92). Some prospective teachers indicated that they found this educational approach as guiding: "STEM is like the polar star, because when we get lost at night, the polar star shows us the way. STEM also helps us find our direction. It gives us light in the dark" (F2.60).

Table 6. Metaphors under the category of STEM as an unnecessary approach

\begin{tabular}{|c|c|c|}
\hline Metaphors & Prospective Teachers & $\mathrm{f}$ \\
\hline Orange color & F1.97/ F3.136/F1.101/F1.68 & 4 \\
\hline A boring book & M1.95/ M1.124/F3.134 & 3 \\
\hline & Total & 7 \\
\hline
\end{tabular}

Some prospective teachers regarded STEM education as an unnecessary approach. The reasons expressed for the metaphors of orange and boring book revealed that the prospective teachers regarded this approach as unnecessary and boring. The following provide a couple of examples of the metaphors used by the prospective teachers under this category: "STEM is like the color orange, because it is 
unnecessary and causes deterioration of the eyesight; it is not a must" (F1.97), and "STEM is like a boring book, because it is boring for me to apply it, no matter how useful and educational" (M1.95).

Table 7. Metaphors under the category of STEM as a constantly improving approach

\begin{tabular}{|c|c|c|}
\hline Metaphors & Prospective Teachers & $\mathrm{f}$ \\
\hline World & F2.46/F2.45/F4.7 & 3 \\
\hline Race & M4.6 & 1 \\
\hline Ladder & F2.56 & 1 \\
\hline & Total & 5 \\
\hline
\end{tabular}

As seen in Table 7, the most used metaphor under this category was world $(\mathrm{f}=3)$. In addition, prospective teachers stated that the STEM fields were constantly evolving and progressing by applying race and ladder metaphors. The prospective teacher who likened STEM to the world described it as follows: "STEM is like the world, because the world has been improving and developing from the past to today. STEM education is improving and developing just like the world" (F2.46). Another aspect expressed under this category was the continuous change and development identified with STEM, using the race metaphor: "STEM is like a race, because it is a constantly renewed science. Science-technology is moving at a tremendous pace in the face of innovations. Like a race one innovation goes beyond the other" (M4.6).

Table 8. Metaphors under the category of STEM as an approach that requires solid infrastructure and work

\begin{tabular}{|c|c|c|}
\hline Metaphors & Prospective Teachers & f \\
\hline Numbers & M4.14 / F2.36/F1.99 & 3 \\
\hline Tangled cables & F1.77/ M2.39 & 2 \\
\hline & Total & 5 \\
\hline
\end{tabular}

In Table 8, the metaphors that emerged under the category of STEM as an approach that requires a solid background and work are shown. The metaphors identified with these ideas were rock and tangled cables. Using these metaphors, the prospective teachers were suggesting that STEM education was made up of difficult fields because they are numeric fields; they require much work and skill: "STEM is like numbers, because all areas are numerical and related to numbers. It requires numerical knowledge. It is difficult to understand without numerical skill" (F2.36). The tangled-cable analogy emphasizes the difficulty of understanding the connections between the fields of STEM education, with one of the prospective teacher's stating, "STEM is like tangled cables, because it requires attention to solve all those connections. It is necessary to observe well and follow the paths of the cables. You need to know the solution and the tactics to solve it so that you can save time while solving it. At the same time, it requires patience" (F1.77).

Table 9. Metaphors under the category of STEM as specific to an individual

\begin{tabular}{|c|c|c|}
\hline Metaphors & Prospective Teachers & $\mathrm{f}$ \\
\hline Flower & F1.120/F3.2 & 2 \\
\hline Total & & 2 \\
\hline
\end{tabular}

In Table 9, the single metaphor flower is seen under the category of STEM as specific to the individuals. In this regard, prospective teachers stated that they regarded STEM education as a personalized approach that allows for the development of individual skills and provides individual teaching opportunities. The prospective teacher who compared STEM education to a flower offered the following metaphor: "STEM is like a flower, because if the students, like the roots of a flower, are raised according to their own skills at a younger age, that plant will grow, and it will create the flower coming from its own genes. That flower will complement a missing blue or red in that garden; maybe like a leaf complementing a deficiency or a cactus trying to survive in a waterless environment"'(F1.120). 
Table 10. Conceptual categories of STEM-related metaphors

\begin{tabular}{|c|c|c|c|c|c|c|c|c|c|c|c|c|c|c|}
\hline \multirow{3}{*}{ Conceptual categories } & \multicolumn{4}{|c|}{ Gender } & \multicolumn{8}{|c|}{ Grade Level } & \multirow{2}{*}{\multicolumn{2}{|c|}{ Total }} \\
\hline & \multicolumn{2}{|c|}{ Female } & \multicolumn{2}{|c|}{ Male } & \multicolumn{2}{|c|}{ First Year } & \multicolumn{2}{|c|}{ Second Year } & \multicolumn{2}{|c|}{ Third Year } & \multicolumn{2}{|c|}{ Fourth Year } & & \\
\hline & $\mathrm{f}$ & $\%$ & $\mathrm{f}$ & $\%$ & $\mathrm{f}$ & $\%$ & $\mathrm{f}$ & $\%$ & $\mathrm{f}$ & $\%$ & $\mathrm{f}$ & $\%$ & $\mathrm{f}$ & $\%$ \\
\hline STEM as mutually complementary areas & 28 & 29 & 9 & 32 & 14 & 27 & 4 & 13 & 14 & 50 & 5 & 36 & 37 & 30 \\
\hline STEM as a useful approach & 23 & 24 & 6 & 21 & 10 & 20 & 11 & 36 & 5 & 18 & 3 & 21 & 29 & 23 \\
\hline STEM as a needed approach & 17 & 18 & 1 & 4 & 13 & 25 & 4 & 13 & 1 & 4 & 0 & 0 & 18 & 14 \\
\hline $\begin{array}{l}\text { STEM as an approach involving different } \\
\text { disciplines }\end{array}$ & 9 & 10 & 3 & 11 & 1 & 2 & 5 & 16 & 3 & 10 & 3 & 21 & 12 & 10 \\
\hline STEM as a highly liked approach & 5 & 5 & 4 & 14 & 5 & 10 & 2 & 6 & 2 & 7 & 0 & 0 & 9 & 7 \\
\hline STEM as an unnecessary approach & 5 & 5 & 2 & 7 & 5 & 10 & 0 & 0 & 2 & 7 & 0 & 0 & 7 & 6 \\
\hline STEM as a constantly improving approach & 4 & 4 & 1 & 4 & 0 & 0 & 3 & 10 & 0 & 0 & 2 & 15 & 5 & 4 \\
\hline $\begin{array}{l}\text { STEM as an approach that requires solid } \\
\text { infrastructure and work }\end{array}$ & 3 & 3 & 2 & 7 & 2 & 4 & 2 & 6 & 0 & 0 & 1 & 7 & 5 & 4 \\
\hline STEM as specific to an individual & 2 & 2 & 0 & 0 & 1 & 2 & 0 & 0 & 1 & 4 & 0 & 0 & 2 & 2 \\
\hline Total & 96 & 100 & 28 & 100 & 51 & 100 & 31 & 100 & 28 & 100 & 14 & 100 & 124 & 100 \\
\hline
\end{tabular}

As seen in Table 10, from the analysis of the metaphors written by the prospective teachers about STEM education, 9 different conceptual categories were formed. Many of the prospective teachers believe that STEM fields complemented one another and that STEM was a useful approach. From the emerging categories, the one with the highest frequency was STEM as fields complementing each other (30\%), followed by STEM as a useful approach (23\%), STEM as a needed approach (14\%),STEM as an approach involving different disciplines (10\%), highly liked (7\%), unnecessary (6\%), constantly improving (4\%), requiring solid background and work (4\%) and specific to an individual (2\%).

In terms of gender, the categories of STEM as fields complementing each other (females 29\%, males 32\%) and STEM as a useful approach (females 24\%, males 21\%) shared the highest representation by both males and females. However, the female teachers had the third highest representation under the category of STEM as $a$ necessary approach (females 18\%, males 4\%), while for males, the third highest representation was under the category of STEM as a highly liked approach (females 5\%, males 14\%). These results show that the majority of both female and male prospective teachers believe that STEM education is beneficial and that they love it.

Considering the year level, while the most frequently stated category by prospective teachers for all years, save for the second year, was STEM as fields complementing each other (first year - 27\%, third year - 50\%, fourth year $36 \%$ ), the second year prospective teachers emphasized had the most metaphors under the category of STEM as $a$ useful approach (second year - 36\%).

\section{Discussion}

STEM education is an innovation-based approach that aims to give students a solid background in quantitative fields by teaching them the relationships between science, technology, engineering and mathematics and to raise interest in the engineering profession. This study has examined the perceptions of prospective classroom teachers on STEM through metaphors. As a result of the study, it was found that the prospective teachers regard STEM education as an approach largely consisting of complementary fields. Prospective teachers believe that science, technology, engineering and mathematics complement one another, and that when addressed together they match the STEM definitions presented in the literature. Breiner et al. [3], in fact, regard STEM education as a single entity, wherein the independent disciplines of science, technology, engineering and mathematics are interconnected. From this study, it was found that the teachers had generally positive attitudes towards STEM integration and considered STEM education to be an important learning approach [10, 36]. Furthermore, the category with the second most metaphors expressed by the prospective teachers was STEM as a useful approach. Prospective teachers likened STEM to technological tools and nutrients in terms of the benefits they provide, and in this way, they emphasized the usefulness of STEM. The benefits of STEM education and its contributions to education are supported by other studies in the literature [16, 37-39]. The category with the third highest frequency of metaphors was STEM as a necessary approach. The metaphors under this category reveal that prospective teachers see STEM education as an approach that is necessary and promising in the development and quality of the education system for student development. This is a finding supported by the literature. For example, in a study on pre-service teachers' STEM engagement, learning and teaching via robotics were investigated in an elementary teacher preparation course [40]. Data analyses from this said study indicated that pre -service teachers engaged in 
robotics activities actively and mindfully and that their STEM engagement improved overall. Moreover, it was shown that their emotional engagement (e.g., interest, enjoyment) in STEM significantly improved and in turn influenced their behavioral and cognitive engagement in STEM.

Another result from the present study was that prospective teachers view STEM education as a combination of the science, technology, engineering and mathematics disciplines, where these related disciplines work in cooperation. Moreover, the other conceptual categories that emerged as a result of data analysis further showed how some prospective teachers perceive STEM education. From these categories, it was determined that the prospective teachers saw STEM as highly liked, constantly evolving, and requiring solid infrastructure and work, or as a tailor -made approach. In the literature, various studies have shown that the STEM approach makes education fun and entertaining [41, 42] and facilitates interest and motivation [40, 43, 44]. The results of the present research found that the prospective teachers generally emphasized the positive features of STEM education. The mention of all these positive features are important in so far as they show that the prospective teachers have adopted this approach and will therefore be able to apply STEM education once they become teachers. At the same time, it is also important to note that some teachers used the metaphors of Numbers and Tangled Cables, which fell under the category, "STEM as an approach that requires solid infrastructure and work". These metaphors suggest that some of the prospective teachers see STEM education as difficult and confusing to understand, which could be attributed to the fact that some of the prospective teachers who participated in the study may not have graduated from the science or mathematical areas in high school and therefore may have weaknesses in these areas. If this study were to be repeated with science or math teacher candidates, the results would likely differ in a positive direction.

The only negative category developed out of the analyses was "STEM as an unnecessary approach". Some prospective teachers stated that STEM education was unnecessary and boring, which could be explained by the fact that STEM involves an educational approach consisting of time-consuming and diverse activities with different numerical fields. In other studies in the literature, one of the negative aspects of STEM education has been reported to be its time consuming approach, but there has never been any mention of it being seen as unnecessary [ 45 , 46].

The basis of STEM education is centered on the idea of establishing a meaningful connection between mathematics and science courses and technology and engineering, whereby the increased success in math and science courses will translate into an enhancement of the country's innovative and engineering workforce. For this reason, it is essential to apply STEM education at all education levels. The first step necessary to accomplish this is to provide a strong, comprehensive STEM education to prospective teachers. STEM courses should therefore be added to the relevant curriculum of the education faculties.

\section{REFERENCES}

[1] J. B. Labov, A. H. Reid \& K. R. Yamamoto. Integrated biology and undergraduate science education: A new biology education for the twenty-first century? CBE-Life Sciences Education, 9(1), 10-16, 2010.

[2] Sanders, M. STEM, STEM education, STEM mania, Technology Teacher, 68(4), 20-26, 2009.

[3] J. M. Breiner, S.S. Harkness, C.C. Johnson \& C.M. Koehler. What is STEM? A discussion about conceptions of STEM in education and partnerships, School Science and Mathematics, 112(1), 3-11, 2012.

[4] J. Smith \& P. Karr-Kidwell. The interdisciplinary curriculum: A literary review and a manual for administrators and teachers, Online available from http://files.eric.ed.gov/fulltext/ED443172.pdf

[5] R. W. Bybee. Advancing STEM education: A 2020 vision, Technology and Engineering Teacher, 70(6), 30-35, 2010.

[6] D. Balka. Standards of mathematical practice and STEM. Math-Science Connector Newsletter. Stillwater, OK: School Science and Mathematics Association, 2011.

[7] P.K. Raju \& A. Clayson. The future of STEM: An analysis of two national reports, Journal of STEM Education, 11.5/6, 25-28, 2010.

[8] OECD (Organization for Economic Co-Operation and Development). PISA 2009 Results: Executive Summary, Online available from https://www.oecd.org/pisa/pisaproducts/46619703.pdf

[9] OECD (Organization for Economic Co-Operation and Development). PISA 2015 Results in Focus, Online available from

https://www.oecd.org/pisa/pisa-2015-results-in-focus.pdf

[10] R. Brown, J. Brown, K. Reardon \& C. Merrill. Understanding STEM: Current perceptions, Technology and Engineering Teacher, 70(6), 5-9, 2011.

[11] J. J. Kuenzi. Science, technology, engineering, and mathematics (STEM) education: Background, federal policy, and legislative action, Congressional Research Service Report, 2008.

[12] A. Zollman. Learning for STEM literacy: STEM literacy for learning, School Science and Mathematics, 112(1), 12-19, 2012.

[13] M. Borrego \& C. Henderson. Increasing the use of evidence-based teaching in STEM higher education: A comparison of eight change strategies, Journal of Engineering Education, 103(2), 220-252, 2014.

[14] M. M. Capraro \& S. B. Nite. STEM integration in 
mathematics standards, Middle Grades Research Journal, 9(3), 1-10, 2014.

[15] A. Surra \& L. S. Litowitz. A STEM-based, high school course, Technology and Engineering Teacher, 74(4), 28-30, 2015.

[16] H. Yamak, N. Bulut \& S. Dündar. 5. Sınıf öğrencilerinin bilimsel süreç becerileri ile fene karș1 tutumlarına FeTeMM etkinliklerinin etkisi, Gazi Eğitim Fakültesi Dergisi, 34(2), 249-265, 2014.

[17] B. Taylor. Evaluating the benefit of the maker movement in K-12 STEM education, Electronic International Journal of Education, Arts, and Science, 2, 1-22, 2016.

[18] E. Susilo, J. Liu, Y.A. Rayo, A. M. Peck, J. Montenegro, M. Gonyea \& P. Valdastri. Storm lab for STEM education: An affordable modular robotic kit for integrated science, technology, engineering, and math education, IEEE Robotics \& Automation Magazine, 23(2), 47-55, 2016.

[19] A. VanMeter-Adams, C. L. Frankenfeld, J. Bases, V. Espina \& L. A. Liotta. Students who demonstrate strong talent and interest in STEM are initially attracted to STEM through extra-curricular experiences, CBE-Life Sciences Education, 13, 687-697, 2014.

[20] S. Han, R. Capraro \& M. M. Capraro. How science, technology, engineering, and mathematics (STEM) project-based learning (PBL) affects high, middle, and low achievers differently: The impact of student factors on achievement, International Journal of Science and Mathematics Education, 13(5), 1089-1113, 2015.

[21] S. B. Nite, M. Margaret, R. M. Capraro, J. Morgan \& C. A. Peterson. Science, technology, engineering and mathematics (STEM) education: A longitudinal examination of secondary school intervention, Frontiers in Education Conference (FIE), 1-7, 2014

[22] T. J. Kopcha, J. McGregor, S. Shin, Y. Qian, J. Choi, R. Hill, J. Mativo \& I. Choi. Developing an integrative STEM curriculum for robotics education through educational design research, Journal of Formative Design in Learning, 1(1), 31-44, 2017.

[23] A. Lee. Multilevel structural equation models for investigating the effects of computer-based learning in math classrooms on science technology engineering and math (STEM) major selection in 4-year post-secondary institutions, Teachers College Record, 119(2), 2017.

[24] Milli Eğitim Bakanlığı. STEM Eğitimi Raporu, Online available from http://yegitek.meb.gov.tr/STEM_Egitimi_Raporu.pdf, 2016.

[25] M. S. Çorlu. FeTeMM Eğitimi Makale Çağrı Mektubu, Turkish Journal of Education, 3(1), 4-10, 2014.

[26] I. M. Yob. Thinking constructively with metaphors, Studies in Philosophy and Education, 22, 127-138, 2003.

[27] C. H. Deant-Reed \& A. Szokolszky. Where do metaphors come from? Metaphor and Symbolic Activity, 8(3), 227-242, 1993.

[28] E. Strenski. Disciplines and communities, armies and aonasteries and the teaching of composition, Rhetoric Review, 8(1), 137-146, 1989.
[29] M. C. M. Guerrero \& O. S. Villamil. Metaphorical conceptualizations of ELS teaching and learning, Language Teaching Research, 6(2), 95-120, 2002.

[30] H. H. Marshall. Metaphor as an instructional tool in encouraging student teacher reflection, Theory into Practice, 29(2), 128-132, 1990

[31] A. Yıldırım \& H. Simşek. Sosyal Bilimlerde Nitel Araștırma Yöntemleri (Sekizinci Baskı) Ankara, Seçkin Yayıncılık, 2011.

[32] H. B. Zheng \& W. J. Song. Metaphor analysis in the educational discourse: A critical review. Online Submission, 8(9), 42-49, 2010

[33] R. L. Oxford, S. Tomlinson, A. Barcelos, C. Harrington, R. Z. Lavine, A. Saleh \& A. Longhini. Clashing metaphors about classroom teachers: Toward a systematic typology for the language teaching field. System, 26(1), 3-50, 1998.

[34] M. Q. Patton. Teaching and training with metaphors. American Journal of Evaluation, 23(1), 93-98, 2002.

[35] A. Saban. Okula ilişkin metaforlar, Kuram ve Uygulamada Eğitim Yönetimi, 55, 459-496, 2008.

[36] A. Delice, E. Aydın, G. Derin \& Ö. Yaşın. An investigation of the views on the integration of science technology and mathematics in a mathematics teacher education program. Boğaziçi University Journal of Education, 32(1), 3-15, 2015.

[37] E. Karahan, S. Canbazoglu Bilici \& A. Ünal. Integration of media design processes in science, technology, engineering, and mathematics (STEM) education, Eurasian Journal of Educational Research, 60, 221-240, 2015.

[38] L. X. Quang, L. H. Hoang, V. D. Chuan, N. H. Nam, N. T. T Anh \& V. T. H. Nhung. Integrated science, technology, engineering and mathematics (STEM) education through active experience of designing technical toys in Vietnamese schools, British Journal of Education, Society \& Behavioural Science, 11(2), 1-12, 2015.

[39] Ö. Ö. Sümen \& H. Çalışıcı. Pre-service teachers' mind maps and opinions on STEM education implemented in an environmental literacy course, Educational Sciences: Theory and Practice, 16(2), 459-476, 2016.

[40] C. Kim, D. Kim, J. Yuan, R. B. Hill, P. Doshi \& C. N. Thai Robotics to promote elementary education pre-service teachers' STEM engagement, learning, and teaching, Computers \& Education, 91, 14-31, 2015.

[41] G. Keçeci, B. Alan \& F. Kırbağ Zengin. 5. sınıföğrencileriyle STEM eğitimiuygulamaları, Kırșehir Eğitim Fakültesi Dergisi, 18, 1-17, 2017.

[42] A. S. Gencer. Fen eğitiminde bilim ve mühendislik uygulaması: Fırıldak etkinliği, Araştırma Temelli Etkinlik Dergisi, 5(1), 1-19, 2015.

[43] V. L. Wyss, D. Heulskamp \& C. J. Siebert. Increasing middle school student interest in STEM careers with videos of scientists, International Journal of Environmental and Science Education, 7(4), 501-522, 2012.

[44] M. J. Mohr - Schroeder, C. Jackson, M. Miller, B. Walcott, D. L. Little, L. Speler, W. Schooler \& D. C. Schroeder. Developing middle school students' interests in STEM via summer learning experiences: See Blue STEM Camp, 
School Science and Mathematics, 114(6), 291-301, 2014.

[45] E. Baran, S. Canbazoğlu Bilici \& C. Mesutoğlu. Fen, teknoloji, mühendislik ve matematik (FeTeMM) spotu geliştirme etkinliği, Araştırma Temelli Etkinlik Dergisi, 5(2), 60-69, 2015.
[46] N. Yılmaz \& C. Pekbay. Fen Bilgisi ve Ilköğretim Matematik Öğretmen Adaylarıyla Yapılan Bir FeTeMM Etkinliğinin Tanıtılması Üzerine Bir Çalışma. International Congress on Politic, Economic and Social Studies, Sarajevo Bosnia Herzegovina, 518- 519, 2017.

i This study was written by modifying and expanding the abstract notice that was presented in International Educational Technology Symposium 27-28 October 2017, Sivas, Turkey. 